\title{
Santa Cruz, Galapagos Electricity sector towards a zero fossil fuel island
}

\author{
Héctor I. Apolo, M.Sc. ${ }^{1,2}$, Kenny Escobar-Segovia, M.Sc ${ }^{1}$, Danilo Arcentales-Bastidas, Ph.D (c) ${ }^{1}$ \\ ${ }^{1}$ Escuela Superior Politécnica del Litoral, ESPOL, Facultad de Ciencias Naturales y Matemáticas, Campus Gustavo Galindo Km. \\ 30.5 Vía Perimetral, P.O. Box 09-01-5863, Guayaquil, Ecuador, hapolo@espol.edu.ec \\ ${ }^{2}$ The University of Melbourne, Australia, hector_apolo@ hotmail.com \\ ${ }^{1}$ Escuela Superior Politécnica del Litoral, ESPOL, Facultad de Ingeniería en Ciencias de la Tierra, Campus Gustavo Galindo Km. \\ 30.5 Vía Perimetral, P.O. Box 09-01-5863, Guayaquil, Ecuador, kescobar@espol.edu.ec, daanarce@espol.edu.ec
}

\begin{abstract}
The Galapagos Islands is one of the world's pristine archipelago. It has been inscribed as an UNESCO World Natural Heritage since 1978 [1]. This archipelago is also well known because Charles Darwin studied the origin of species in these islands. However, it is in great threat due to the main energy source is diesel. Hence, the Ecuadorian government has an initiative called 'Zero fossil fuel in the Galapagos Islands' which aims to reduce diesel consumption by replacing it for renewable energy. In this context this research will show the electricity sector market mix particularly of Santa Cruz island, in order to indicate how much is done and needs to be done to become an island fossil fuel free in electricity generation. It will present a literature review as well as novel information from electricity generated in 2014 by the solar $P V$ power plant of Santa Cruz and a forecasted wind generation of 2014 of Santa Cruz base on wind speeds from a meteorological tower. It concludes that even though the significant efforts of international cooperation to co fund renewable energy projects in order to increase its installed capacity, almost $80 \%$ of the electricity is generated by thermoelectric turbines run by diesel.
\end{abstract}

Keywords—solar PV, wind energy, Santa Cruz, renewable energy, Baltra.

\section{INTRODUCTION}

The Galapagos Islands has been inscribed as an UNESCO World Natural Heritage since 1978 [1]. Considering the variety of endemic species, that make the archipelago one of the richest marine reserves, it is also one of the most environmentally protected and conserved marine ecosystems [2]. Despite of, being a World Natural Heritage and having more than $96 \%$ of the land surface declared as protected areas [3] it is in great danger due to the main energy source for electricity generation is diesel. The current electricity supply of the island makes them vulnerable and highly dependent on fossil fuels shipped from mainland Ecuador, therefore is not sustainable [4].Also, the diesel electricity generation emits greenhouse gases and expose the island to the risk of diesel leakages. Moreover, a big natural disaster already happened in 2001 when the diesel tanker "Jessica" spilled roughly 75000 gallons of fuel oil and 70000 gallons of diesel on the coast of the islands, causing severe environmental impacts [3], [5]. The costs associated with this disaster were of approximately USD

Digital Object Identifier (DOI):

http://dx.doi.org/10.18687/LACCEI2019.1.1.170

ISBN: 978-0-9993443-6-1 ISSN: 2414-6390
10 million [5]. Six years after this natural disaster, in April 2007 the Ecuadorian government launched the program "Zero fossil fuel in the Galapagos Islands" which aims to eradicate the use of fossil fuels for electricity generation by 2020 [1]. After economic, political and technical issues, this initiative is showing results, for instance in 2014 two new renewable energy power plants were inaugurated in Santa Cruz increasing the renewable energy electricity production in approximately $15 \%$ [6]. However, the fossil fuel consumption has continue increasing in the islands as the energy demand has increased [7]. It is important that the archipelago continue mitigating climate change by reducing the greenhouse gases emissions, considering that it may impact the emblematic species and as consequence the tourist industry and the whole archipelago may suffer economic losses [8]. This research aims to provide insides that can help to the initiatives of reducing fossil fuel in electricity generation continue growing particularly in Santa Cruz Island. Firstly, it presents the social context since it influences in the energy demand. It covers areas such as climate, population, political division and tourism. Secondly, it focuses in the Galapagos electricity sector and more in ddtail \$locsatitaccondifoxwer plants. Finally, it shows a conclusion about the Galapagos electricity market mix.

Galapagos Islands is an archipelago located in the Pacific Ocean approximately $1000 \mathrm{~km}$ far from Ecuador mainland [9], [10]. It has one of the most biodiverse ecosystems of our planet and is home of endemic species such as the emblematic giant tortoises, fur sea lion and the marine iguanas [3]. Due to the currents of Tropical, Sub-tropical and sub-Antarctic that converge in the Galapagos Marine Reserve, enabling a wide range of biological communities to coexists such as penguins, hammerhead sharks and tropical corals [3]. Also, the archipelago has 760 endemic species of animals and plants [11]. The islands are also part of the migratory routes of whales, marine turtles and dolphins [3]. Small islands such as Galapagos are vulnerable to the negative effects of climate change, for example coral bleaching, sea level rise, reduction of fresh water resources and extreme climatic events [3], which can have adverse impacts in the tourism industry. The main driver of the economy is the tourism which represents 68 $\%$ of the income of the archipelago, followed by fishing and agriculture [9]. The following Fig. 1 summarizes the most important facts of the archipelago [11].

$17^{\text {th }}$ LACCEI International Multi-Conference for Engineering, Education, and Technology: "Industry, Innovation, And Infrastructure for Sustainable Cities and Communities", 24-26 July 2019, Jamaica. 


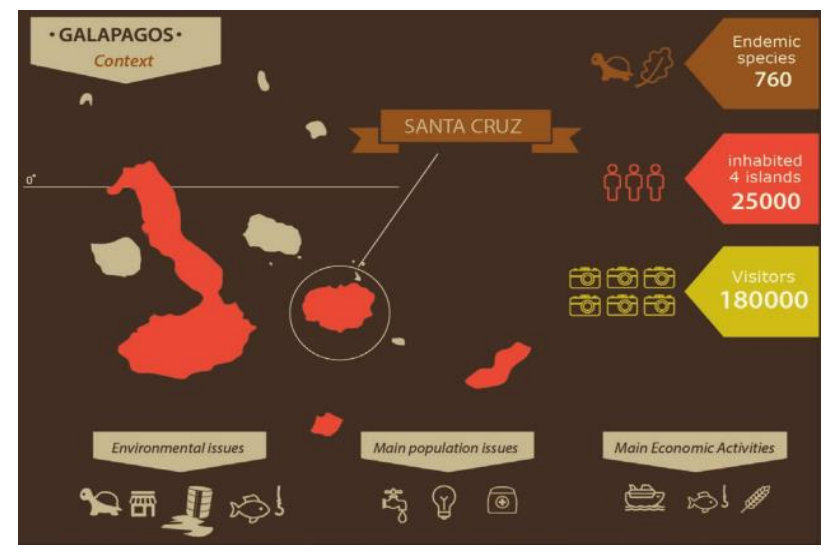

Fig. 1 Galapagos context [11]

A. Climate

Since the archipelago is located over the equator, it has two seasons, which are summer and winter [12]. The summer season is from December to May, where it is characterized for clear skies, high solar irradiation and low wind speeds. On the other hand, the winter season, which is from June to November, it is characterized for cloudiness, higher precipitations and high wind speeds. The average annual temperature of Santa Cruz is $24.1^{\circ} \mathrm{C}$ [5]. The following Fig. 2 was generated using actual energy generated in 2014 by the solar PV power plant of Santa Cruz and the forecasted wind generation of 2014 of Santa Cruz base on wind speeds. Its seasonality of the wind and solar resources has a positive correlation with the electricity generation from this renewable energy sources.

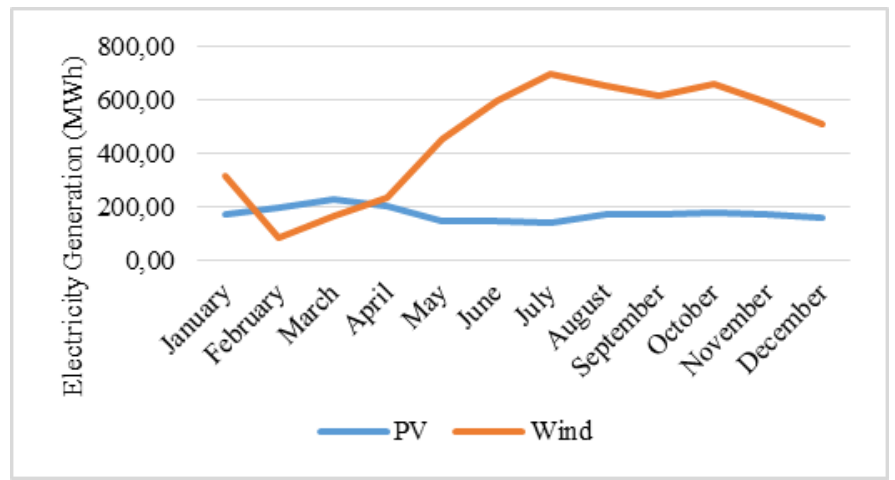

Fig. 2 PV and Wind seasonality electricity generation 2014

\section{B. Population}

More than $60 \%$ of the Galapagos Islands population lives in Santa Cruz [13], particularly in its capital city called Puerto Ayora. The city of Puerto Ayora is the most important city of the archipelago, having the largest population [12]. The following Fig. 3 generated with data of the last census done in 2010 shows the population distribution per canton. Despite that Isabela Island is the largest in size, it has the small percentage of population.
-San Cristobal Isabela $\quad$ Santa Cruz

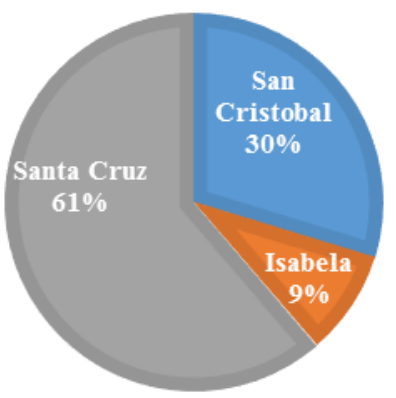

Fig. 3 Population Distribution per Canton [15]

Overall, the population of the archipelago since the first census in the island in 1950 was almost doubling each census, until year 2001 [13], as it is shown in the Fig. 4. As a result, the archipelago population has increased in $157 \%$ in the past two decades [7]. However, from the census of the year 2001 onwards the population has increased in a lower rate. This is due to in 1998 the Organic Law of Especial Regiment of Galapagos (LOREG, Spanish acronym) created a restriction for tourists to become residents of the island [14]. As part of this new law the tourists that were staying longer than the time allowed in the islands were deported and banned to return to the archipelago for one year [2]. According to the last census done in 2010 the yearly population grow is approximately of $3.3 \%$.

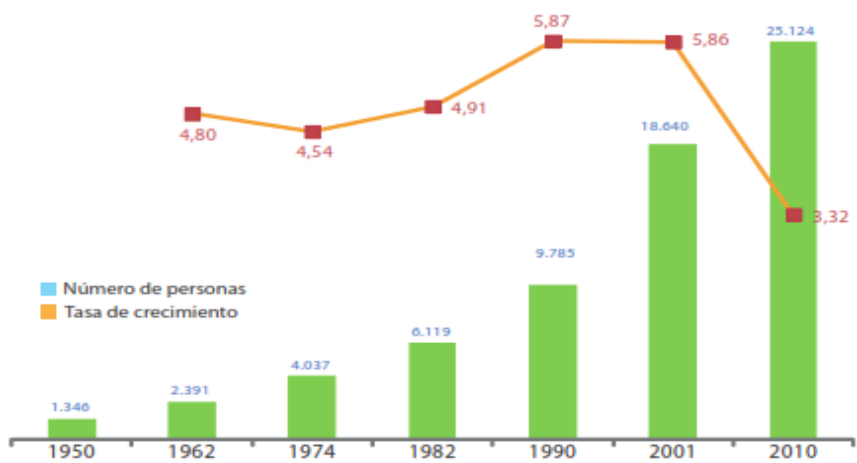

Fig. 4 Population Grow from the Ecuadorian census [15]

The population of Santa Cruz in 2010 census was of 16000 habitants approximately [15], followed by Santa Cristobal and finally Isabela, as it is shown in Table I.

TABLE I

GALAPAGOS POPULATION

\begin{tabular}{|l|l|l|l|l|}
\hline \multicolumn{1}{|c}{ Island } & \multicolumn{1}{c}{ Urban } & \multicolumn{1}{c|}{ Rural } & Total \\
\hline $\begin{array}{l}\text { San } \\
\text { Cristobal }\end{array}$ & 6672 & 658 (El Progreso) & 145 (Floreana) & 7475 \\
\hline Isabela & 2092 & 164 (T. Berlanga) & -- & 2256 \\
\hline Santa Cruz & 11974 & 2425 (Bellavista) & $\begin{array}{l}\text { 994 (Sta. Rosa } \\
\text { y Baltra) }\end{array}$ & 15393 \\
\hline Total & 20738 & Total Rural: 4386 & $\mathbf{2 5 1 2 4}$ \\
\hline
\end{tabular}

$17^{\text {th }}$ LACCEI International Multi-Conference for Engineering, Education, and Technology: "Industry, Innovation, And Infrastructure for Sustainable Cities and Communities", 24-26 July 2019, Jamaica. 
Using the data of the last population census a population forecast has been developed for Santa Cruz Island, according to the 20 years' time of this research analysis Fig. 5. The following figure shows that the population of Santa Cruz in the year 2030 will be approximately 22000 .

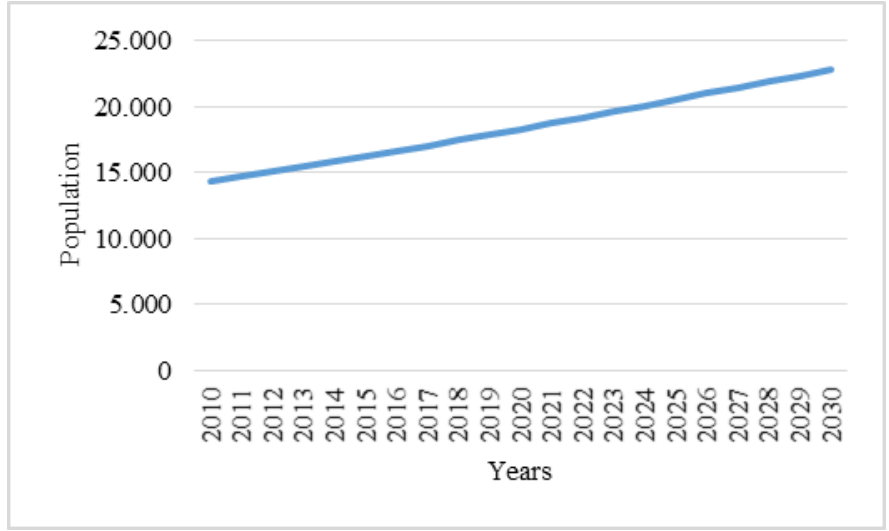

Fig. 5 Population forecasts of Santa Cruz Island [15]

\section{Political Division}

Galapagos archipelago has 13 big islands with nearly 8000 $\mathrm{km} 2$ of land surface and 112 small islands and islets [3]. From the 13 big islands only 4 are inhabited which are Floreana, Isabela, San Cristobal y Santa Cruz [16]. The islands are the peaks of underwater volcanoes [3]. The archipelago is a province part of Ecuador and it is politically divided in 3 cantons: Santa Cruz, San Cristobal and Isabela [10]. The capital is Puerto Baquerizo Moreno located in San Cristobal Island. Santa Cruz Island has its capital city Puerto Ayora and two rural town Bella Vista and Santa Rosa [5]. Baltra Island is located 400 metres far from Santa Cruz Island. In Baltra it is located an international airport and has a small military population [17]. In 1959 the Ecuadorian Government established $96.7 \%$ of the terrestrial surface of the archipelago as a National Park. Therefore, the remaining difference of $3.3 \%$ which represents 26.356 ha can be used as rural and urban areas for the population [9], [3]. The following map shows the main islands of the archipelago, Floreana Island can be found as Isla Santa Maria which is the other name of the island as shown in Fig. 6.

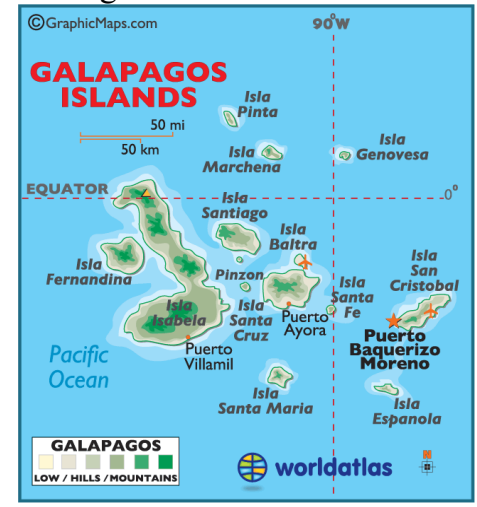

Fig. 6 Galapagos main islands

\section{Tourism}

The number of tourists that has visit the archipelago per year has been increasing steadily every year as is shown in Fig. 7. Overall, the number of visitors has increased in approximately $321 \%$ in the past two decades [7]. The vertical axis shows the number of visitors to the National Park in thousands.

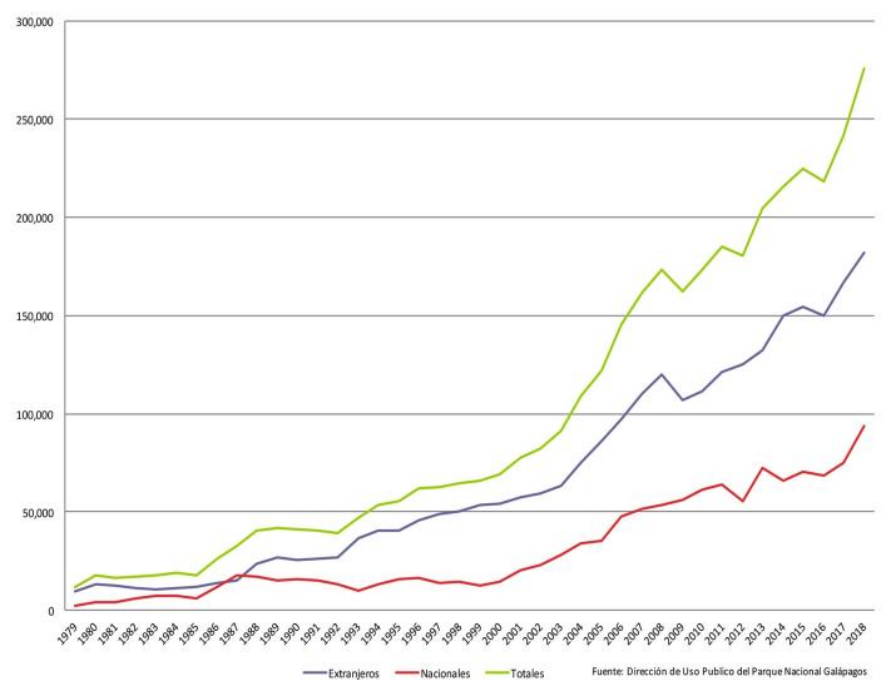

Fig. 7 Number of visitors to the Galapagos National Park per year [18]

According to the following figure the island most visited is Santa Cruz. The increasing trend of visitors to the archipelago can be like the trend of visitors for Santa Cruz Island since this island has one of the two international airports and the most developed tourism facilities and larger amount of tourism companies. Moreover, the four inhabited Island are approximately 2 hours far from each other by boat, therefore the visitors go to the different island while they are in the archipelago. The second island that receive most tourists is San Cristobal due to it has the other international airport and it is the capital of the province.

The following Table II shows the forecasted number of tourists that are expected to visit the archipelago for the next 15 years until the year 2030 [9]. It is expected that the number of tourists will increase steadily in a rate of approximately $7.8 \%$ per year [9]. Which at the same time will increase the demand for electricity in the islands, particularly in Santa Cruz. Nowadays, already the tourism is the main energy consumption sector [7]. The growing rate of $7.8 \%$ is a moderate scenario considering that other literature states that the tourism sector is growing $14 \%$ per year [3].

$17^{\text {th }}$ LACCEI International Multi-Conference for Engineering, Education, and Technology: "Industry, Innovation, And 
TABLE II

Forecasted number of tourists until the year 2030

\begin{tabular}{|c|c|}
\hline \multicolumn{2}{|c|}{$\begin{array}{c}\text { Tourism } \\
\text { Projection }\end{array}$} \\
\hline Year & Total \\
\hline $\mathbf{2 0 1 5}$ & 238,913 \\
\hline $\mathbf{2 0 1 6}$ & 257,735 \\
\hline $\mathbf{2 0 1 7}$ & 278,039 \\
\hline $\mathbf{2 0 1 8}$ & 299,943 \\
\hline $\mathbf{2 0 1 9}$ & 323,573 \\
\hline $\mathbf{2 0 2 0}$ & 349,065 \\
\hline $\mathbf{2 0 2 1}$ & 376,565 \\
\hline $\mathbf{2 0 2 2}$ & 406,231 \\
\hline $\mathbf{2 0 2 3}$ & 438,235 \\
\hline $\mathbf{2 0 2 4}$ & 472,761 \\
\hline $\mathbf{2 0 2 5}$ & 510,006 \\
\hline $\mathbf{2 0 2 6}$ & 550,186 \\
\hline $\mathbf{2 0 2 7}$ & 593,532 \\
\hline $\mathbf{2 0 2 8}$ & 640,292 \\
\hline $\mathbf{2 0 2 9}$ & 690,737 \\
\hline $\mathbf{2 0 3 0}$ & 745,157 \\
\hline
\end{tabular}

It is important to mention that tourism market has shifted from specialized nature visitors to generic nature lovers [8]. Moreover, almost $100 \%$ of the tourists used to fly to the archipelago and housed on diving cruise ships during the whole time they spend in the islands, but nowadays the majority on the tourists stay in hotels in the islands and hire local boats to move around the archipelago [2]. As a result, there is an increasing demand on hotels, restaurants and goods and services in the islands, which means there is an increasing demand for electricity.

\section{ELECTRICITY SECTOR}

The electricity sector in Ecuador is regulated and controlled by the state. However, $51 \%$ of the generation, transmission and distribution can be owned by private companies [19]. The electricity system is protected by the Law of Electricity Sector (LRSE) and the following institutions are part of it: The National Electricity Council (CONELEC) is the controlling and regulating body [19]. Part of the role of CONELEC is to grant concessions or approve the installation of new generation units, this can be from renewable or non-renewable sources [19]. Other main institution part of the Ecuadorian electricity market is The National Centre for Energy Control (CENACE). CENACE manages the commercial and technical transactions and prepares operative plans [19]. Transelectric, which is another public enterprise, is responsible of the transmission of generation in mainland Ecuador [19]. Currently, the electricity in mainland Ecuador is generated almost half by oil thermal generators and the other half by hydroelectricity [20]. However, mainland Ecuador is targeting to have $80 \%$ of the electricity generation from Hydro power by 2020 .

Mainland Ecuador has a national electricity grid called the Ecuadorian National Integrated System. Galapagos is the only province of Ecuador that is not connected to the Ecuadorian
National Integrated System because of the distance from mainland [19], hence it works in isolation [21]. Moreover, even the four inhabited islands are not interconnected among them; therefore, each have an independent energy grid. But the only exception is Baltra and Santa Cruz that have a submarine electricity transmission cable that transmits the electricity generated from the wind farm in Baltra to Santa Cruz. As they are only 400 meters far from each other. On the other hand, Galapagos Islands has ELECGALAPAGOS S.A. which is the company responsible of the generation, transmission, distribution and retailing of the electricity [19]. The electricity service coverage of the archipelago is of 99.28\% [22]. However, Galapagos has a fragile and insecure electricity system, since it mostly relies on diesel fuel shipped from mainland Ecuador as primary source of energy [19]. This make the islands vulnerable to suffer blackouts if there is a supply chain interruption of diesel or gas, which will impose social and economic costs [7]. This shipment has also risked of diesel spills in the ecosystem, like it happened in year 2001 when a diesel tanker sunk near the coast of San Cristobal, spilling approximately 75000 gallons of fuel oil and 70000 gallons of diesel [3]. This caused the dead of 10000 marine iguanas among other species [23]. The cost of remediation of this accident was of approximately USD \$10 million [3]. This trigger, in 2007 to the Ecuadorian government to create the initiative "Zero Fossil Fuels in the Galapagos" which aimed to eliminate the use of fossil fuels by 2020 [24], [7]. The three main aims of this governmental initiative are:

- Increase wind, solar and biofuel power plants to eliminate the diesel thermal electrical generation.

- Increase the number of electric and hybrid vehicles and adapt diesel engines to biofuel and finally to use biofuel for tourism and fishing boats [23].

However, due to financial, technical and political problems it has not been installed enough amount of renewable energy capacity and the consumption of diesel in the island is still increasing [7]. Moreover, it is estimated that 2.4 million gallons of diesel [23], which emits more than 20000 tons of $\mathrm{CO} 2$, are still been use for electricity generations of Galapagos per year. Hence, there is a great acceptance of renewable energy development by the Galapagos community of $93 \%$ according to the study done by Ref. [7]. However, in the archipelago in 2012 the main source of electricity generation was still diesel, supplying almost $80 \%$ of the Galapagos Island electricity demand [23].

On the other hand, energy in the Galapagos Islands are heavily subsidized same as in mainland Ecuador, therefore reducing the diesel consumption will reduce the expending in subsidies [7]. Moreover, the subsidy of diesel in 2004 for Ecuador was USD \$260 million [3]. The highest demand of fossil fuels in Galapagos Islands is from the transport sector, particularly from the maritime transport [19]. The maritime transport

$17^{\text {th }}$ LACCEI International Multi-Conference for Engineering, Education, and Technology: "Industry, Innovation, And Infrastructure for Sustainable Cities and Communities", 24-26 July 2019, Jamaica. 
represents $65 \%$ of the total energy demand. This is due to the tourism boats that work as taxis around the islands or inter island, as well as the boats that are used for fishing activities. The second biggest fuel consumption sector is the electricity sector which consumes $19 \%$ of the fuel imported, as Fig. 8 shows.

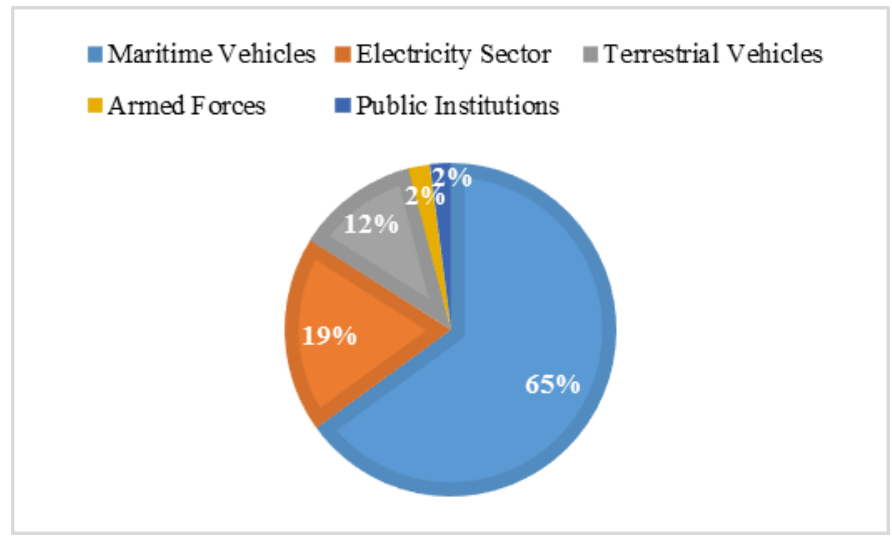

Fig. 8 Fossil fuel consumption by sector 2010 [7]

The electricity consumption of the Galapagos Island is mainly demanded by two sectors, the residential sector which is the largest $(44 \%)$ and followed by the commercial sector $(32 \%)$. The industry sector only represents $4 \%$ of the total electricity consumption of the islands as shown in Fig. 9 [7].

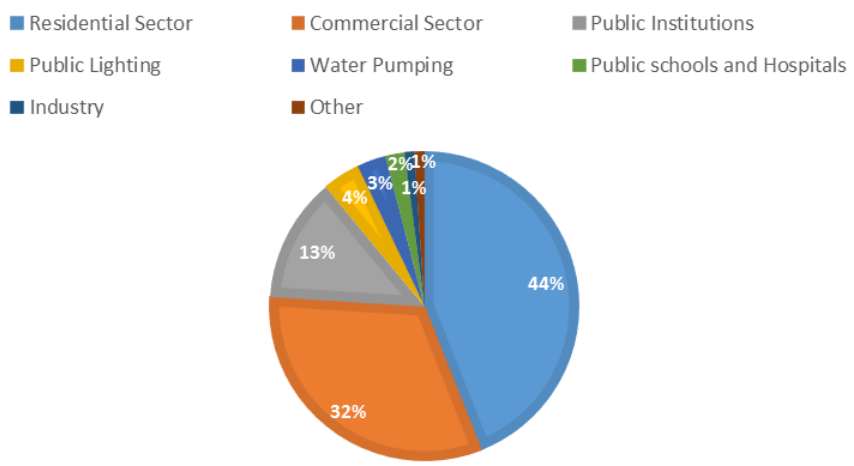

Fig. 9 Electricity consumption by customer 2010 [7]

\section{A. Feed-in Tariff (FiT)}

As a renewable energy incentive CONELEC created a new regulation in year 2013 for Feed-in Tariff having different tariff for Ecuador mainland and the Galapagos Islands [26]. This regulation was meant to last until the end of year 2016 where it was going to be revised [26]. However, the FiT last period is of 15 years starting from the registration day [26]. Once a company is registered for this tariff, they will receive the following prices for mentioned 15 years [26]. Solar PV is not included in this incentive, while wind energy it is included, making the wind energy economically better off as shown in Table III.
TABLE III

FIT CONELEC

\begin{tabular}{|l|l|l|}
\hline \multicolumn{1}{|c|}{ Technology } & \multicolumn{1}{c|}{$\begin{array}{c}\text { Mainland } \\
\text { price } \\
\text { (cUSD\$/kWh) }\end{array}$} & $\begin{array}{c}\text { Galapagos islands price } \\
\text { (cUSD\$/kWh) }\end{array}$ \\
\hline Wind & 11.74 & 12.91 \\
\hline Solar thermal & 25.77 & 28.34 \\
\hline Wave & 32.43 & 35.67 \\
\hline Biomass and biogas & 11.08 & 12.19 \\
\hline Geothermal & 13.81 & 15.19 \\
\hline
\end{tabular}

\section{B. Santa Cruz power plants}

The Santa Cruz electricity demand is supplied by three main energy sources, thermal, wind and solar PV energy. The thermoelectricity technology is the greatest installed generation capacity now in Santa Cruz with $60 \%$ of the total installed capacity. The second biggest is wind and the third is solar PV as shown in Fig. 10.

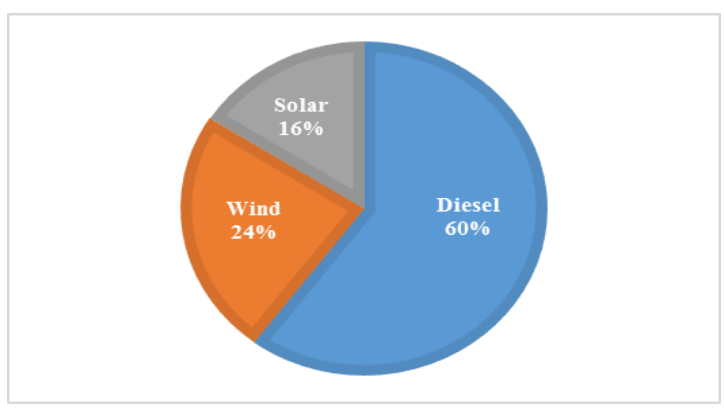

Fig. 10 Santa Cruz electricity generation installed capacity

Fig. 11 bellow shows the electricity generation mix of Santa Cruz of the year 2014. It can be noticed that despite that the installed capacity of diesel generation is $60 \%$ of the total installed capacity of Santa Cruz, for electricity production diesel generation represents almost $80 \%$ of the total supply. This is due to the capacity factor of diesel generation is higher than the wind and the solar energy. That mean that the installed capacity can operates more hours per day.

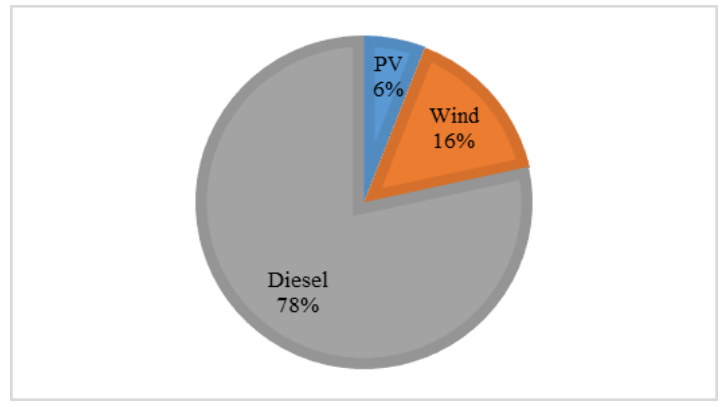

Fig. 11 Electricity supply mix Santa Cruz 2014

C. Thermal Electric power plants

The thermal electric power plants installed capacity in Santa Cruz island is of $5.68 \mathrm{MW}$, which consists of 5 thermal 
generators brand Caterpillar from year 1990 and 2 Hyundai from year 2011 of different effective power, between 520 to $1360 \mathrm{~kW}$ [16]. The historic capital cost of a diesel generator power plant built in Santa Cruz in 2012 is of approximately USD 3.17/w [25]. Mention generators are run by diesel fuel hence the cost of this commodity is crucial for calculating the cost of electricity generation per $\mathrm{kWh}$.

The average retail price of electricity in Galapagos Island is of USD $0.104 / \mathrm{kWh}$ [22], which is higher than USD 0.0823 per $\mathrm{kWh}$ that is charged in mainland Ecuador [21]. The real cost of electricity generation in Santa Cruz is of USD 0.256 per $\mathrm{kWh}$ without diesel subsidies [27]. While the price of generating electricity with subsided diesel price is USD 0.131 per $\mathrm{kWh}$ [4]. The deficit between retail cost and retail price is covered by the Ecuadorian Finance Ministry, through the Rural and Urban Marginal Electrification Fund [27]. The following Table IV summarizes the retail price and costs of electricity generation.

TABLE IV

GALAPAGOS ELECTRICITY PRICES/KWH

\begin{tabular}{|c|c|c|}
\hline Electricity & Amount & Source \\
\hline Average retail price Galapagos & $\begin{array}{l}\text { USD } \\
0.104 / \mathrm{kWh}\end{array}$ & (ARCONEL 2014) \\
\hline $\begin{array}{l}\text { Average retail cost Galapagos } \\
\text { (subsidized diesel) }\end{array}$ & $\begin{array}{l}\text { USD } \\
0.131 / \mathrm{kWh}\end{array}$ & $\begin{array}{l}\text { (Alvarez \& Pacheco } \\
\text { 2011) }\end{array}$ \\
\hline $\begin{array}{l}\text { Average retail cost Galapagos } \\
\text { (unsubsidized diesel) }\end{array}$ & $\begin{array}{l}\text { USD } \\
0.256 / \mathrm{kWh}\end{array}$ & (Jacome 2006) \\
\hline
\end{tabular}

This is mainly to the costs of transporting diesel from mainland Ecuador adding a cost of approximately USD 0.209 per gallon [4]. The fuel efficiency of the thermal generators is of approximately $11.5 \mathrm{kWh}$ of electricity per gallon of diesel [28]. The real cost of diesel placed on Santa Cruz is approximately USD $2.515 /$ gallon [27]. The price charge per gallon of diesel is USD 1 [29] for transport usage and USD 0.92 per gallon for electricity generation. The electricity diesel subsidy is of approximately USD 1.595 per [27]. The total subsidy for Santa Cruz electricity was USD 2.47 million in 2005, incorporating the real cost of diesel [27]. In average every MWh of electricity generated using diesel emits 0.5669 tonnes of $\mathrm{CO} 2$ [30]. There is no carbon price implemented in Ecuador, however in Chile there is a carbon tax of USD 5 per tonne of $\mathrm{CO} 2$ released [31]. The following Table V summarizes the main costs of diesel for electricity generation.

TABLE V GALAPAGOS DIESEL PRICES/GALLON

\begin{tabular}{|l|l|l|}
\hline \multicolumn{2}{|c|}{ Diesel } & \multicolumn{1}{c|}{ Amount } \\
\hline $\begin{array}{l}\text { Real cost placed in Santa } \\
\text { Cruz }\end{array}$ & USD 2.515/gallon & (Jacome 2006) \\
\hline $\begin{array}{l}\text { Subsidized cost for electricity } \\
\text { placed in Santa Cruz }\end{array}$ & USD 0.92/gallon & (Jacome 2006) \\
\hline Carbon Dioxide emissions & $\begin{array}{l}0.5669 \\
\text { tonnesCO2/MWh }\end{array}$ & $\begin{array}{l}\text { (CTDFEGEI } \\
\text { 2011) }\end{array}$ \\
\hline
\end{tabular}

\section{Wind energy power plant}

Santa Cruz has one wind farm which is in Baltra Island, it consists of 3 wind turbines UNISON57 of $750 \mathrm{~kW}$ each adding a total effective power of $2.25 \mathrm{MW}$ [22]. This wind farm project execution was funded by international cooperation and the Ecuadorian Government. The Global Environment Fund (GEF), the United Nations Fund (UNF) and the Ecuadorian Government (MEER) provided non-refundable funds (Rosero \& Chiliquinga 2011).

The wind farm starts generating electricity in the year 2014 and was officially inaugurated the 22nd of December of 2014 [6]. The feasibility study was done by Pro Viento S.A. [24]. However, there were other studies done; for instance, one done by the consulting firm Lahmeyer where it was concluded that Baltra Island has the better wind resource, comparing with two other locations in Santa Cruz which are Santa Rosa and El Camote [32]. Baltra Island has an annual average wind speeds of $6 \mathrm{~m} / \mathrm{s}$ [24]. Besides the good wind speeds, Baltra used to be a USA military base therefore it has an already ecological modified area, decreasing the environmental impacts of the project [24]. The following Fig. 12 shows the wind farm which is located next to the Seymour Airport and supplies $65 \%$ of its electricity, the remaining $35 \%$ is provided by solar PV panels and has battery storage [33].

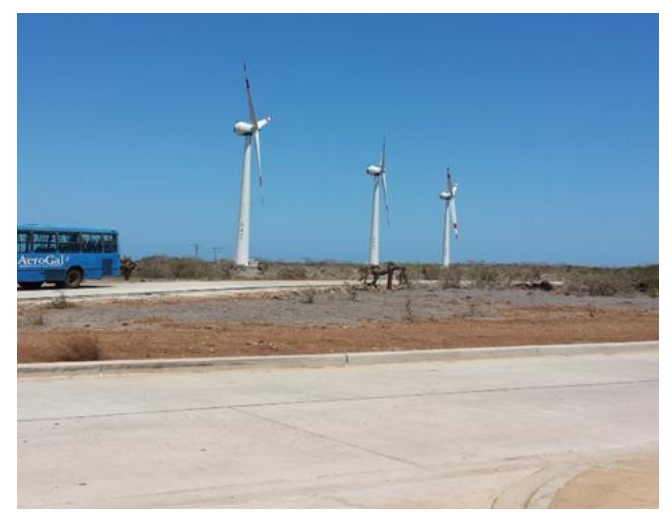

Fig. 12 Wind farm at Baltra

Baltra Island is separated from Santa Cruz for less than one kilometre. To interconnect the wind farm from Baltra to Santa Cruz, an undersea transmission line was installed. The underwater transmission line has a length of approximately 850 metres, transmission capacity of $34.5 \mathrm{kV}$ [37], and a transmission voltage regulation capacity of $9.5 \mathrm{MW}$. Mention underwater transmission cable is using just a capacity of 2.25 MW for transmission of the wind farm electricity to Santa Cruz, leaving a buffer of transmission capacity of approximately $7.25 \mathrm{~W}$ for future developments.

The total cost of the underwater cable transmission line was of approximately USD 15 million [34]. The total cost of the project (wind farm + interconnection system) was of roughly USD 26 million, therefore the cost of the wind farm project

$17^{\text {th }}$ LACCEI International Multi-Conference for Engineering, Education, and Technology: "Industry, Innovation, And 
was of USD 11 million yielding a capital cost of USD 4.89/W [35].

\section{E. Solar PV power plant}

The solar power plant of Santa Cruz is in Pampas Coloradas, Puerto Ayora. It has 6006 solar panels of $250 \mathrm{Wp}$ each adding a total nominal power of $1.52 \mathrm{MW}$ [22]. This project was developed with direct bilateral cooperation of Ecuadorian Government (MEER) and the Korean Government (KOICA), through a loan and a non-refundable cooperation fund (Rosero \& Chiliquinga 2011).

A company called BJ POWER oversaw building and installing the power plant. The total capital cost was of approximately USD 10.6 million which yields a capital cost of USD 7.07/W [36]. The power plant started generating electricity in May of 2014 and was inaugurated the 22nd of December of 2014 [6]. The following Fig.13 shows the solar PV power plant of 1.5MW located in Puerto Ayora. The solar PV arrays have a minimum slope of $10^{\circ}$ for self-cleaning by rainfall purposes and maximum efficiency, considering that the archipelago is located over the equator.

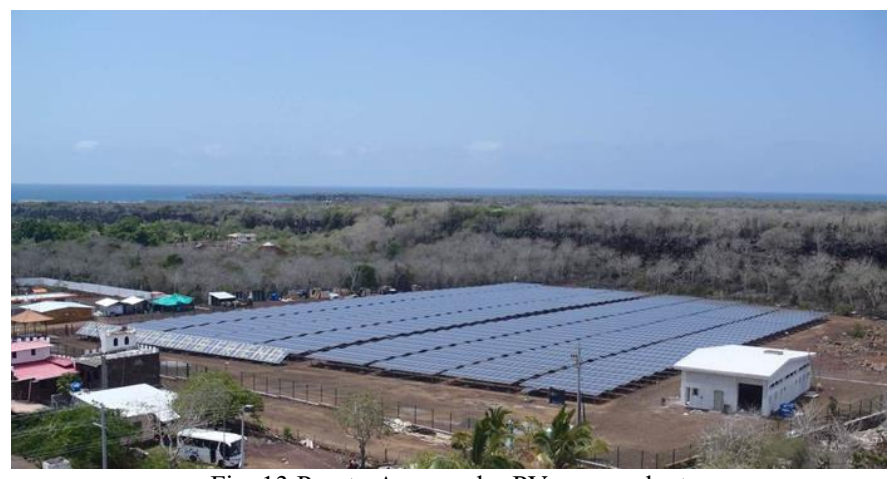

Fig. 13 Puerto Ayora solar PV power plant

Source: http://www.korea.net/NewsFocus/policies/view?articleId=124281

There other smaller power plants located in Santa Cruz, one has a nominal power rate of $10 \mathrm{~kW}$ and the other one which is in the Seymour Airport, Baltra has a nominal power capacity of $200 \mathrm{~kW}$ with battery storage [37]. The later power plant uses building-integrated solar PV roof in the airport walkways as shown in Fig. 14.

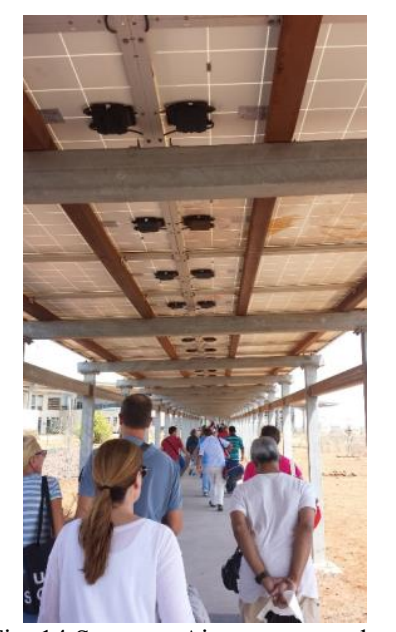

Fig. 14 Seymour Airport power plant

$F$. Renewable energy in the rest of the archipelago

There are three types of renewable energy technology installed in the archipelago, this are: wind, solar PV and biofuel power plants. All the different renewable energy power plants installed have been developed with international collaboration agencies from different countries [23]. Since each island has an independent electricity grid it is propitious for install and test modern off grid renewable energy technologies.

San Cristobal: It has the first wind farm large scale project installed in the Ecuador [3]. It has an installed capacity of 2.4 MW and had an approximately cost of USD 10 million which was developed from a partnership between the Ecuadorian Government and the United Nations Development Programme (UNDP) [3], [28].

Isabela: It has a $1.3 \mathrm{MW}$ biofuel power plant that runs with the oil extracted from jatropha curca plant [23]; and a 1MW solar PV power plant that joined with the biofuel thermal power plant has a hybrid electricity system. This hybrid power plant system was installed in collaboration with GIZ and KfW Development Bank on behalf of BMZ from Germany [38].

Floreana: It has a like the Isabela hybrid system of biofuel from jatropha curca and solar PV power plant. It was firstly installed in this island considering that only has a population of 120 habitants therefore it is much smaller. The two biofuel engines add an installed power capacity of $138 \mathrm{~kW}$ and was developed in collaboration of the German agency GIZ [38]. The following Fig. 15 shows the jatropha oil storage tank. 


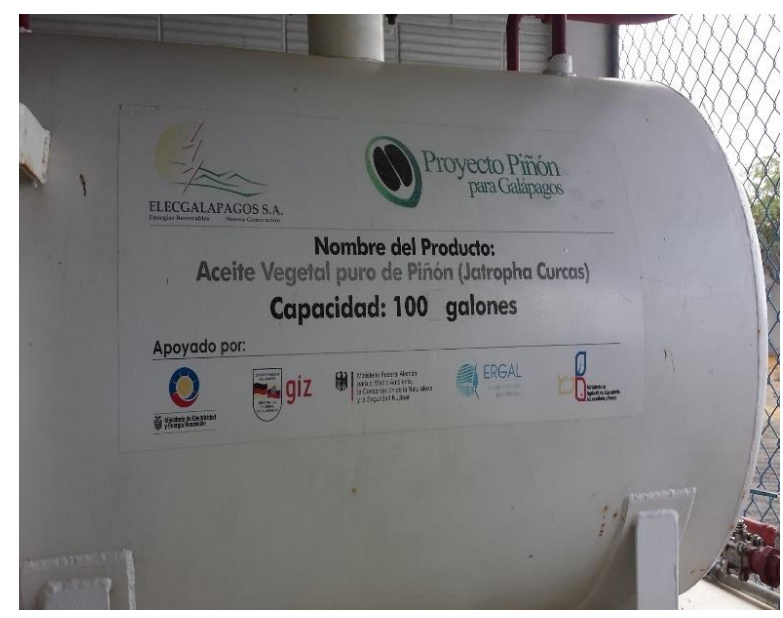

Fig. 15 Floreana biofuels storage tank

The solar PV power plant has an installed power capacity of $20.6 \mathrm{kWp}$ and was developed in collaboration of Cooperacion Espanola [23]. The following Fig.16 shows the building integrated solar PV power plant.

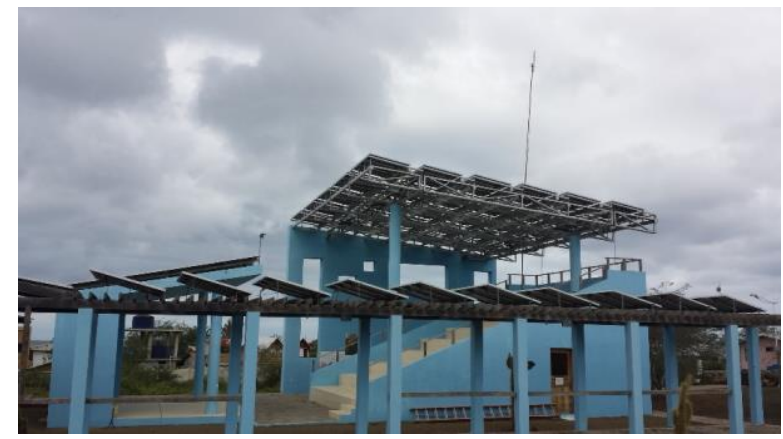

Fig. 16 Floreana solar PV power plant

\section{PROJECTS}

A new PV power plant has been started to build in Baltra, this project has an estimated installed capacity of $65 \mathrm{~kW}$ and a hybrid storage system of $4000 \mathrm{kWh}$ lead-acid batteries and $250 \mathrm{kWh}$ lithium-ion batteries [39].

Also, in order to decrease the diesel consumption in tourism boats, the Ecuadorian government provided to Santa Cruz the first solar power PV water taxi for tourists transport [39]. Solaris as shown in Fig. 17 was made in Galapagos as a pilot program and is a stepping stone considering that the transport sector is the largest energy demand of the archipelago.

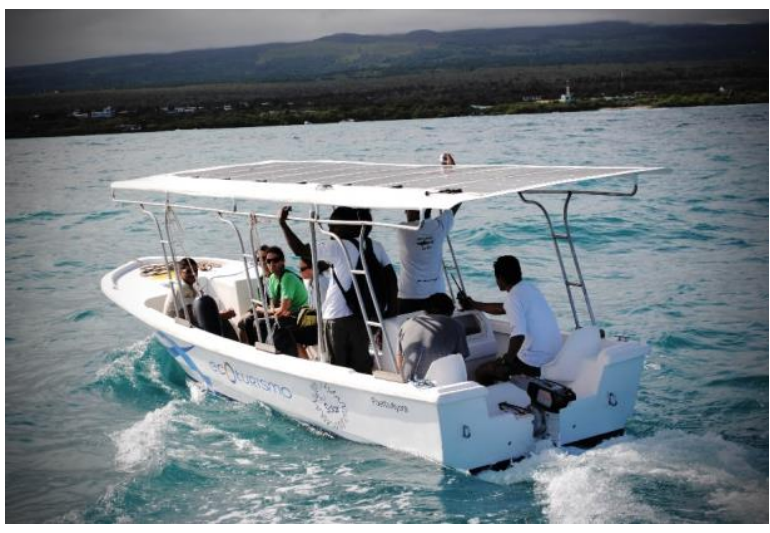

Fig. 17 solar power PV water taxi for tourists transport Source:http://d2ouvy59p0dg6k.cloudfront.net/img/original/wwf_lanchasolar_ 20agosto2013_1.jpg

Looking at Costa Rica fossil free efforts, it shows that other type of projects has to be developed at the same time to dramatically decrease the fossil fuel islands consumption for instance electric vehicles, solar water heaters, bio digesters for organic waste [40].

\section{CONCLUSIONS}

It has been shown in this paper that even though there are many different renewable energy technologies installed in the archipelago, the renewable energy market share is still less than 25\% in Santa Cruz island. Overall, Galapagos relies in diesel thermoelectric power plants. The second largest power plant is the wind energy followed by the PV power plant. On the other hand, it is shown that the majority of the renewable energy projects has been co funded with international cooperation. International cooperation has played and will play an important role to continue increasing the renewable energy share and get closer to reach the propose goal of a zero-fossil fuel island. Also the diesel subsidies significant reduces the operation costs of the thermoelectric power plants.

\section{FURTHER RESEARCH}

Demand side management would be a relevant area to research about in order to estimate how electricity consumption can be optimized. Also considering that San Cristobal Island has one natural permanent lake 700 meters above sea level, it would be interesting to research about how this can be used as a pump hydro storage energy system, and how it can increase the reliability on renewable energy technology.

\section{VII.ACKNOWLEDGMENT}

To M.Sc. Victor Velez, from ELECGALAPAGOS S.A. for having provided relevant information and guidance during the technical visit to the Galapagos power plants. 


\section{REFERENCES}

[1] Estrella, R, Strauss, P, Braun, M, Karres, S, Klaus, W, Rodriguez, I, Moreno, A, Samaniego, A \& Manzano, L 2011, 'PV-Battery-Biofuel Hybrid System for Zero Fossil Fuel Electricity Generation on the Galapagos Islands', Fraunhofer Institute for Wind Energy and Energy System Technology.

[2] UNESCO 2010, 'Galapagos Islands, Ecuador'.

[3] e8 2008, The San Cristobal Wind and Solar Projects.

[4] Álvarez, M \& Pacheco, M 2011, 'Proceso de producción de biodiesel usando aceite de jatropha curcas y su uso en generación térmica de las Islas Galápagos aspectos técnicos y económicos', ESPOL.

[5] Lahmeyer, I 2001, 2001:ECU/97/G41 Electrificación Renovable de las Galápagos Eliminación de las Barreras que Impiden el Desarrollo de la Energía Renovable en el Ecuador, Programa de Naciones Unidas para el Desarrollo Ecuador.

[6] MEER 2014, 'Inauguración proyecto eólico baltra y parque fotovoltaico puerto ayora', <http://www.energia.gob.ec/inauguracion-proyecto-eolicobaltra-y-parque-fotovoltaico-puerto-ayora/>.

[7] Westerman, A 2012, 'An analysis of energy consumption on the Galápagos Islands: Drivers of and solutions to reducing residents' energy consumption', Journal of public and international affairs, vol. 23, pp. 109-30.

[8] Larrea, I \& DiCarlo, G 2011, Climate Change Vulnerability Assesment of the Galapagos Islands, WWF and Conservation International, Quito, Ecuador.

[9] Carrion, C 2007, 'Estudio de previsión de la demanda de energía para las islas Galápagos: escenarios socioeconómicos', Proyecto ERGAL.

[10] IICA 2013, Experiencias exitosas en bioeconomía, Instituto Interamericano de Cooperación para la Agricultura Montevideo, Uruguay.

[11] Calle, P 2014, 'Sustainable Energy Strategies for Santa Cruz Island, Galapagos', Delft University of Technology.

[12] Lahmeyer, 2003, Estudio de Factibilidad Energias Renovables, Islas Galapagos, Ecuador, Programa de Naciones Unidas para el Desarrollo Ecuador.

[13] Granda, L \& Salazar, C 2013, 'Población y migración en Galápagos', Informe Galápagos 2011-2012, pp. 44-51.

[14] LOREG 1998, Ley Organica de Regimen Especial de Galapagos, Ecuador.

[15] INEC 2010, Resultados del Censo 2010 de poblacion y vivienda, Instituto Nacional de Estadisticas y Censos, Quito.

[16] DED 2008, Sustitucion de combustibles fosiles por biocombustible en la generacion de energia electrica en la Isla Floreana, Coperacion Ecuador y Republica Federal de Alemania, Quito.

[17] Baring-Gould, I \& Corbus, D 2006, 'Modeling Results of Wind/Diesel Retrofit Options for Santa Cruz, Galapagos ', National Renewable Energy Laboratory.

[18] Dirección de Uso Público del Parque Nacional Galápagos, Ministerio de Ambiente $\quad$ Ecuador, <http://www.galapagos.gob.ec/wpcontent/uploads/2016/12/Visitantes-1979-2018.jpg>
[19] Peláez-Samaniego, MR, Garcia-Perez, M, Cortez, LAB, Oscullo, J \& Olmedo, G 2007, 'Energy sector in Ecuador: Current status', Energy Policy, vol. 35 , pp. 4177-89.

[20] Santin, J 2009, SOLAR AND WIND ENERGY: Is Sustainable Energy a Viable Way to Solve Ecuadorian Energy Problems?, American University, Washington, DC.

[21] CONELEC 2009, Plan Maestro de Electrificacion 2009-2020, Consejo Nacional de Electricidad, Ecuador.

[22] ARCONEL 2014, 'Atlas del Sector Electrico Ecuatoriano', Agencia de regulacion y control de electricidad.

[23] Carvajal, P 2012, 'Galápagos Islands Zero Fossil Fuels Initiative', <http://www.irena.org/DocumentDownloads/events/MaltaSeptember2012/Pa blo_Carvajal.pdf $>$.

[24] ERGAL 2008, Technical Review of the Feasibility Study for the Wind Energy Project Santa Cruz/Baltra (Galápagos Islands), Renewable Energy for the Galápagos Islands.

[25] Custode, R 2011, Consulting for information on renewable energy installations and existing data for potencial of renewable energy resources survey Form 1, Organizacion Latinoamericana de Energia, Quito, Ecuador.

[26] CONELEC 2013, CND ELECTRICIDAD 2013, REGULACION No. CONELEC - 001/13

[27] Jacome, C 2006, 'Energy Subsidies in Galapagos', Galapagos Report 2006-2007, vol. Socioeconomic Issues.

[28] GSEP 2013, Galapagos San Cristobal Wind Project 2007-2013, Global Sustainable Electricity Partnership, Ecuador.

[29] Faisal, T 2012, 'Forecasting and Analysis of the Potential Renewable Resources for Ecuador's Power Sector (2012-2032)', University of Applied Sciences Cologne.

[30] CTDFEGEI 2011, Factor de Emisión de CO2 del sistema nacional interconectado del Ecuador al año 2011, MEER, MA, Conelec, Cenace, Quito.

[31] Reuters 2014, 'Chile becomes the first South American country to tax carbon', <http://uk.reuters.com/article/2014/09/27/carbon-chile-taxidUKL6N0RR4V720140927>.

[32] ERGAL 2010, Alternativas de construccion de un parque eolico para suminstro energetico en Santa Cruz, Ministerio de Electricidad y Energia Renovable del Ecuador, Quito.

[33] ECOGAL 2015, Aeropuerto Ecologico Galapagos, <http://www.ecogal.aero/en/sustainable-construction>.

[34] Telegrafo, E 2014, 'En Galápagos se ejecutan catorce proyectos eléctricos', El Telegrafo.

[35] Elecgalapagos 2014, Proyecto Parque Eólico Baltra 2.25MW, con aportes PNUD-GEF, Elecgalapagos, viewed 22/october/2015 2015, <http://www.elecgalapagos.com.ec/proyecto-e\%C3\%B3lico-baltra-225-mw5>.

[36] Elecgalapagos 2015, Proyecto Fotovoltaico Puerto Ayora 1,5 MWp Cooperacion KOICA, Elecgalapagos, viewed 22/october/2015 2015, $<$ http://www.elecgalapagos.com.ec/proyecto-fotovoltaico-puerto-ayora-15mwp-cooperacion-koica>.

$17^{\text {th }}$ LACCEI International Multi-Conference for Engineering, Education, and Technology: "Industry, Innovation, And Infrastructure for Sustainable Cities and Communities", 24-26 July 2019, Jamaica. 
[37] ERGAL 2014, Boletín de prensa No. 01-2014, $<$ http://www.ergal.org/boletin.php?c=1503>.

[38] Heinemann, E 2014, ERGAL-Energías renovables para Galápagos, GIZ, <https://www.giz.de/en/downloads/giz2014-sp-factsheet-energal.pdf>.

[39] MEER 2015, Ministerio de Electricidad y Energia Renovable comprometido en la conservacion de Galapagos, by

[40] Cegesti 2011, 'Costa Rica, Final Report', Observatory of Renewable Energy in Latin America and The Caribean, vol. Product 3: Financial Mechanism.

$17^{\text {th }}$ LACCEI International Multi-Conference for Engineering, Education, and Technology: "Industry, Innovation, And Infrastructure for Sustainable Cities and Communities", 24-26 July 2019, Jamaica. 